\title{
Preparation and Analysis of Cement Bricks Based on Rice Straw
}

\author{
Hend Ahmed ${ }^{1}$, Ibrahim M. Ibrahim ${ }^{1}$, M. A. $\operatorname{Radwan}^{1}$, M. A. Sadek ${ }^{1}$, Hany A. Elazab ${ }^{1,2 *}$ \\ ${ }^{1}$ Department of Chemical Engineering, The British University in Egypt, El-Shorouk City, Cairo, Egypt. \\ ${ }^{2}$ Nanotechnology Research Centre (NTRC), The British University in Egypt (BUE), El-Sherouk City, Suez Desert \\ Road, Cairo, 11837, Egypt. \\ * Corresponding Author: elazabha@vcu.edu
}

\begin{abstract}
In Egypt, rice straw is burnt as an easy and the cheap method to get rid of it leads to making a giant black cloud covers Cairo and southern delta governorates. Main purpose of this research is to produce green brick of cement and in-expensive agriculture waste (rice straw) with law price and good characteristics of thermal insulation and acoustic resistance. Different samples of cement brick based on rice straw of many percentage were prepared. First, select best mixture of concrete brick before adding rice straw after preparing and leave for curing time. Then, rice straw is added with various percentage based on total mass of dry mixture to selected concert brick mixture. The selection of best mixture of green bricks criteria is first depending on achieving minimum compression strength according to Egyptian specification then maximizing the percentage of rice straw added. The two mixtures of cement bricks that have maximum compression strength are 1:2:2 and 1:4:5 of 6.2 and 3.1 MPa. The highest percentage of rice straw can be added to later cement mixture is 3\% additional quantities based on total mass of mixture dry base of $2.9 \mathrm{MPa}$. The impact of $3 \%$ addition of rice straw on cement bricks enhances thermal by $21.05 \%$ by comparing with cement brick of ratio 1:2:2. It decreases sound pressure level inside room from 62 $\mathrm{dB}$ to $45 \mathrm{~dB}$. Although, cement bricks reduce sound pressure level to $55 \mathrm{~dB}$. Thousands of cement bricks with $3 \%$ rice straw cost is less $8.3 \%$ the cost of thousand of cement brick with market ratio 1:4:5. Cement brick of ratio 1:4:5 that used by OPAKI company in Egypt for cement brick manufacturing is used with adding $3 \%$ of rice straw. Whatever, it gives very low resistance against compression lower than Egyptian specifications. This mixture of 3\% rice straw base is enhanced by nano-silicon addition percentage of sand portion of 2.1 MPa compression test, although cost of thousand bricks is almost equal to the cost of thousands of commercial market bricks. Eventually, life cycle assessment of rice straw is better than normal cement brick mixture materials
\end{abstract}

that helps in reducing greenhouse emissions and energy consumed.

Key Words: Rice straw, Agricultural waste, Pollution, Cement bricks.

\section{PROBLEM STATEMENT}

Around $9.7 \%$ of total agriculture waste produced in Egypt every year are only rice straw. Rice straw one of renewable waste. In Egypt, more than $90 \%$ are burnt as an easy and the cheap method to get rid of it. This have a negative impact on environment by causing smokes of $\mathrm{CO}, \mathrm{CO}_{2}, \mathrm{NOx}$ and SOx. Therefore, rice straw is available inexpensive material that used in construction as mud houses in rural area and in ancient Egypt. Moreover, produce sustainable cement bricks based on good thermal and sound insulation with respecting to the Egyptian minimum compression strength of non-load bearing wall will leads to saving energy.

\section{RESEARCH OBJECTIVE \& METHODOLOGY}

Main purpose of this research is to produce green brick of cement and in-expensive agriculture waste (rice straw) with law price and good durability characteristics of thermal insulation and acoustic resistance. First select best mixture of concrete brick before adding rice straw as a filler. Determine to how much the maximum percentage of adding rice straw from total mass of brick that must achieve Egyptian minimum compression strength of non-load bearing specification and fire resistance. Furthermore, the utilization of rice straw solves its environmental impact.

Thermal insulation performance of bricks is related to energy consumption by reducing the utilization of heaters in winter and air conditionals in summer. These energies are consumed because of changing climate and unsustainable strategy of buildings. Nowadays, it is concerned on energy saving and 
environmental issues [1-20]. In Europe, $40 \%$ of total energy consumption is inefficient energy loss within building wall. Improving insulating properties of building is important [21-33]. Bricks production consume high energy and resources. Manufacture step is not only effect on environment but also usage step "position", material and their thickness qualify thermal comfort conditions inside buildings [34-56]. Sustainable bricks do not only mean that material should be thermal effectively only, but also sound insulation for decreasing disturbance and noise impact, permeability of water vapor, resistance against fire and effect on human and environment [57-62]. Bricks are solids moulded with different materials. Bricks manufacturing materials are contributing to durability of construction. Todays, world try to replace sand by renewable and nonrenewable unrecyclable waste. Aim of sand replacement is to get rid of wastes to reduce pollution, greenhouse emissions and for saving money [61-63]. Green materials should be characterized with prevent toxic and other emissions, safe built environment, saving energy and water, and conserving natural resources according to environmental building news. The utilization of straw bale has many advantages on environment. Although, these advantages are reducing greenhouse emissions during production and thermal insulation, the usage of this bale faces many challenges as organic nature and absorption of water from surrounding must be taken into consideration [64-69].

The types of bricks are important according to type nature of building and aim of this building. Bricks classified into fired and unfired bricks or cement based and clay based. There are different types of bricks; clay, cement, fly ash, sand-lime and fire bricks. Bricks should be sustainable that means building bear for very long time, they should be resisting and withstand any natural effects with minimum damage, and it is studying of bricks based on also environmental emissions, energy consumption and cost, etc. It also could be sustaining the minimum load strength based on specifications [7-9]. Concrete is widely used throughout world with production rate 3.8 million tonne/year. Main properties of bricks are the mechanical and durability that depend on manufacture process. Nowadays, it is focused on upgrading properties of bricks as thermal insulation and sound insulation with meeting compression strength specification. This upgrading depends on adding industrial and agricultural wastes.

The usage of fiber in construction processes occurred from ancient is used as a material of bricks and masonry mortar. fibres may be straw or horsehair. Nowadays, its focused on using these fibres in many engineering processes as ceramics and concrete production. Utilization of fibers improve properties of concrete such as impact resistance, thermal insulation, tensile strength, and shrinkage [10]. Main components of natural organic fibers are cellulose, hemi-cellulose, and lignin.

Natural fibers are renewable wastes available with low cost [11].Rice associates with large quantities of agriculture wastes that is obtained from harvest stage of rice. It is the most causing solid waste problem of rice crop. Average rice consumption is 477 million per year throughout world [12]. So, rice crop is the second production in agriculture crops.Solid wastes that generate are bran, broken rice, straw, ash, and husk. One of them is rice straw of high-volume generation that its disposal makes problems.FAS Cairo forecasts Egypt's marketing year (MY) 2018/19 (October-September) milled rice production is about 3.3 million metric tons (MMT) corresponding to Planting 800,000 feddan (Egypt: Update to Egypt's Rice Production, Consumption, and Trade Figures, 2018). Rice straw is known a fibrous lignocellulosic material that contains $41.8 \%$ of cellulose, $21.6 \%$ of pentosans, $13.6 \%$ of lignin, $18.4 \%$ ash and $16.7 \%$ of silica (Dry base) based on chemical egyptain rice straw analysis $[5,8,13-15]$. Rice straw is an agriculture waste associated from rice crop. It accumulates during early step which is harvest step. It left to dry by exposing to sunlight or by put it into microwave dryer. This drying is necessary for making grinding into powder is easier. The average length of rice straw after grinding less than $0.5 \mathrm{~mm}$. The rice straw is cleaned and dried at $80{ }^{\circ} \mathrm{C}$ for $8 \mathrm{hr}$. Rice straw can be treated against $\mathrm{NaOH}[6,10,14-17]$.

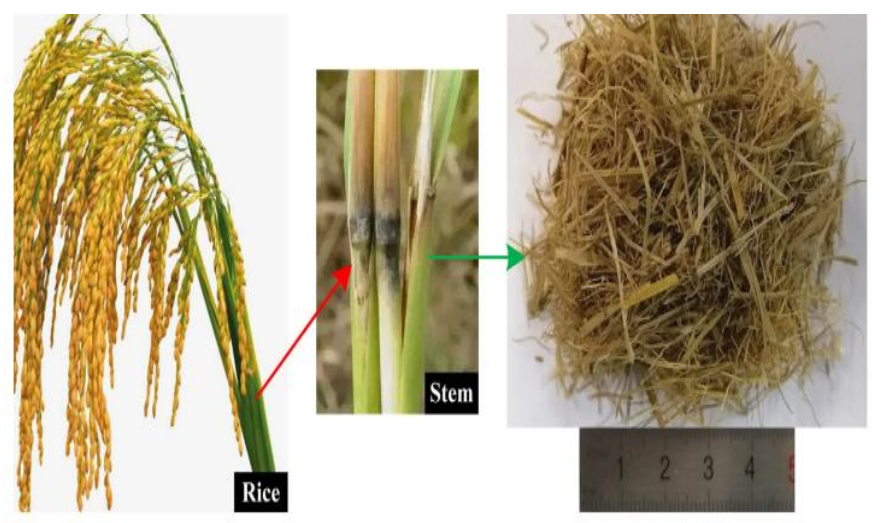

Figure 1Rice Straw Generation Steps [11]

\section{EXPERIMENTAL WORK}

\subsection{Compression test}

Every mix of rice straw cement brick, three samples were examined in the Lab. Another three plugs with tandard commercial cement bricks were examined to 
check the compression stresses of these bricks. Bricks dimensions were checked and measured precisely with an average $6 * 6 * 6 \mathrm{~cm}$ dimensions. The Shumadsu $1000 \mathrm{KN}$ universal tension-compression apparatus, made in China was utilized in examining the bricks compressions. The apparatus is equipped with an output unit of data analysis for output data recordings. The three rice straw bricks combine and mix under examining were prepared and checked for standard pure cement characteristics. Bricks were placed horizontally on the testing machine. A 1 $\mathrm{mm} / \mathrm{sec}$ rate of applying loadings on each specimen until observing a failure. The compression testing results for all bricks mixings are presented in result chapter. These results were compared to the specified values obtained by the Egyptian Code of Practice ECOP 204-2005.

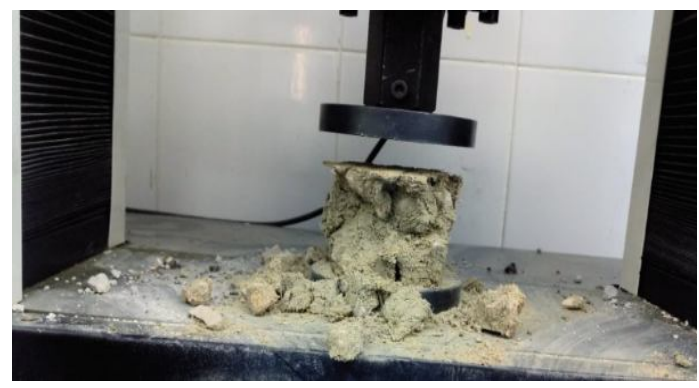

Figure 2 Cement brick with rice straw and glass powder addition after applying compression test

\subsection{Thermal Insulation Test}

Two hot plates are faced and separated by about $20 \mathrm{~cm}$ distance from each other. Both are adjusted at $250{ }^{\circ} \mathrm{C}$ temperature. Ex-tech 5-in-1 Environmental meter is used for temperature measurements. 15 minutes is sufficient for increasing temperature and making constant reading of Ex-tech 5-in-1 Environmental meter of the surrounding between two plates. Reading of surrounding become constant at temperature $60^{\circ} \mathrm{C}$ after 20 minutes. Small room of 12 cement bricks is built as shown in figure below so that there is no space of air among bricks. Dimensions of room is $25 * 4 * 6 \mathrm{~cm}$. Ex-tech 5 -in- 1 Environmental meter is placed inside this room for 10 minutes. Reading is recorded and repeated for cement bricks with $3 \%$ of rice straw addition.

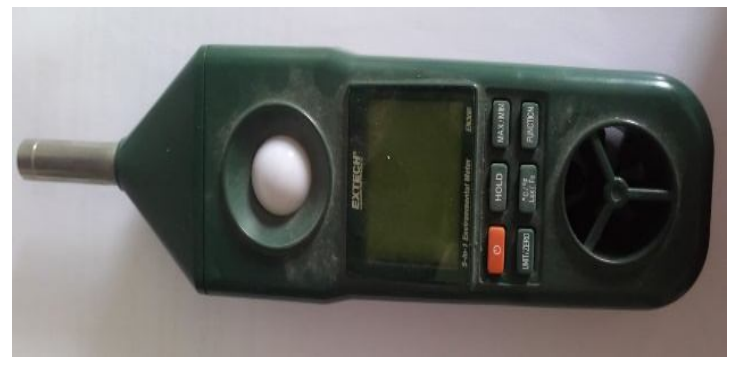

Figure 3Ex-tech 5-in-1 Environmental Meter

\subsection{Sound Insulation Test}

Small room of prepared cement bricks is built to cover instrument which act as receiver of sound. This receiver of laboratory scale is Ex-tech 5-in-1 Environmental meter. Range of measuring Ex-tech 5in-1 Environmental meter is 30 to $130 \mathrm{~dB}$ with error $\pm 1.4 \mathrm{~dB}$. Source is loud sound of sound pressure level about $62 \mathrm{~dB}$. Ex-tech 5-in-1 Environmental meter is placed inside room for 5 minutes to give constant reading with high accuracy. Same procedures were repeated for cement brick of base rice straw samples.

\section{RESULTS}

\subsection{Cement bricks}

- Compression resistance of cement bricks based on cement and sand on the content of the sand

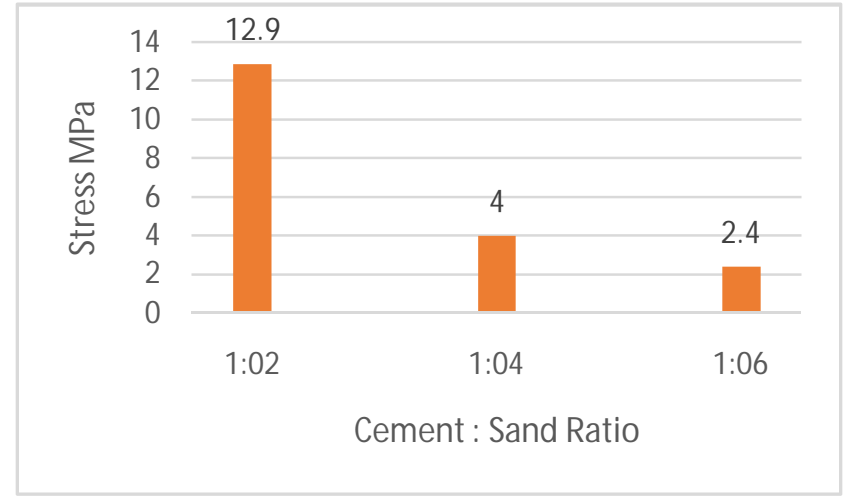

Figure 4 Compression resistance of Cement-Sand bricks with different ratios

It is obvious that the amount of cement in the mixture of the cement bricks effects on the compression strength of the bricks because cement may be responsible of compactness in the brick mixture. As shown in fig, the amount of sand in brick increases the compression decreases due to decrease the concentration of cement which is the binder in Cement-Sand bricks. Therefore, Amount of cement is added in the mixture of cement bricks is directly proportional to the compression strength. Cementsand bricks are used for smooth surface of interlocks manufacture but for building bricks consists of cement, sand and aggregate as an ingredient according to Opaki Company in Egypt. 


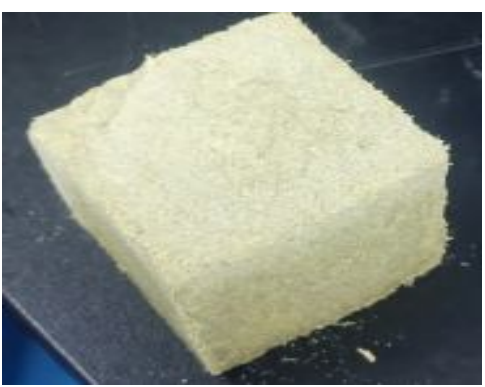

Figure 5Cement-Sand Brick of rice straw based

4.2 Compression strength of cement bricks based on cement, sand, and aggregate on the content of grit with different ratios

Compression strength of cement-sand bricks is put into consideration for comparing them with Concrete bricks that consist of cement, sand and aggregates and show the impact of adding aggregates. From ratio $1: 2: 2$ to $1: 4$ as shown in figures 5 and 6 , it obvious that compression strength of $1: 2: 2$ is $6.2 \mathrm{MPa}$ higher than 1:4 which is $4 \mathrm{MPa}$. Samples 1:2:6 and 1:4:4 can be compared as a decreasing in aggregates amount added to the mixture of bricks. This decreasing affects negatively by $66.67 \%$ of compression from 3.9 MPa of 1:2:6 to 1.3 MPa of 1:4:4. Bricks mixture of different ratios in figure, shows that the addition of aggregates increase the resistance against load until point at which mixing of mixture and binding by cement become difficult. Therefore, figure 8-8 shows there is an optimum point of concrete brick ratio. It is clear the optimum ratio in the curve of figure is 1:4:5.

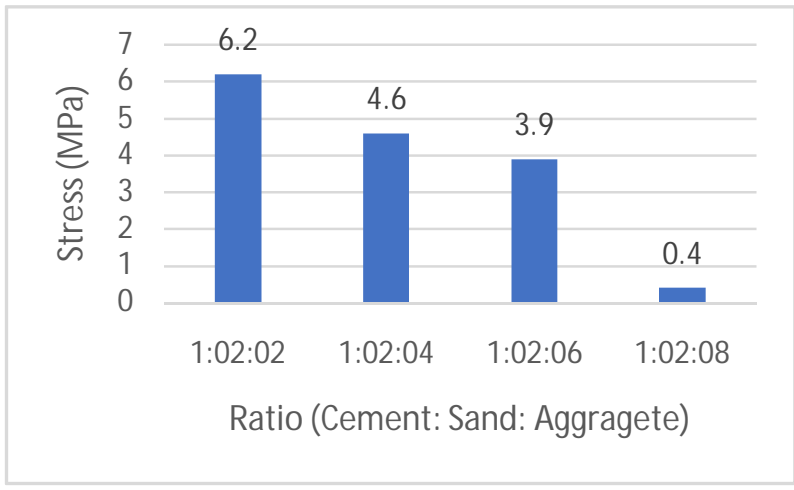

Figure 6Compression strength based on Contents of Cement bricks consist of cement, sand and aggregates with different ratios (1:2: no.)
Furthermore, Opaki company for cement bricks manufacturing, in Egypt is producing their bricks for construction of buildings with ratio 1:4:5 also. This test objective provides the best mixture that can be added rice straw. It was chosen 1:2:2 ratio of brick mixture which has highest compression strength of 6.2 $\mathrm{MPa}$ for adding rice straw with different

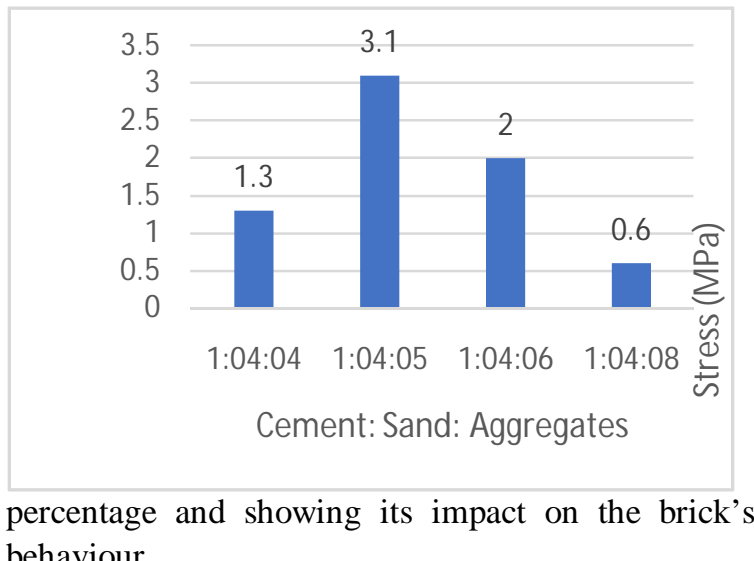
behaviour.

\subsection{Compression resistance of green bricks "Cement bricks of ratio 1:2:2 with addition rice straw different percentage" comparing with Cement-Sand bricks of ratio 1:4 based on rice straw}

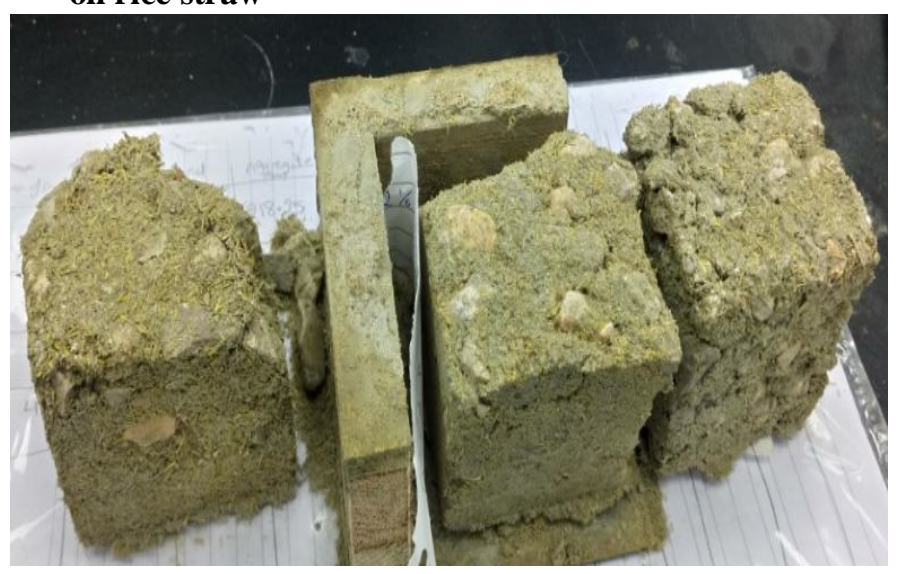

Figure 8Three different percentage of rice straw added to Cement brick 1:2:2 ratio consists of: cement, sand and aggregates 


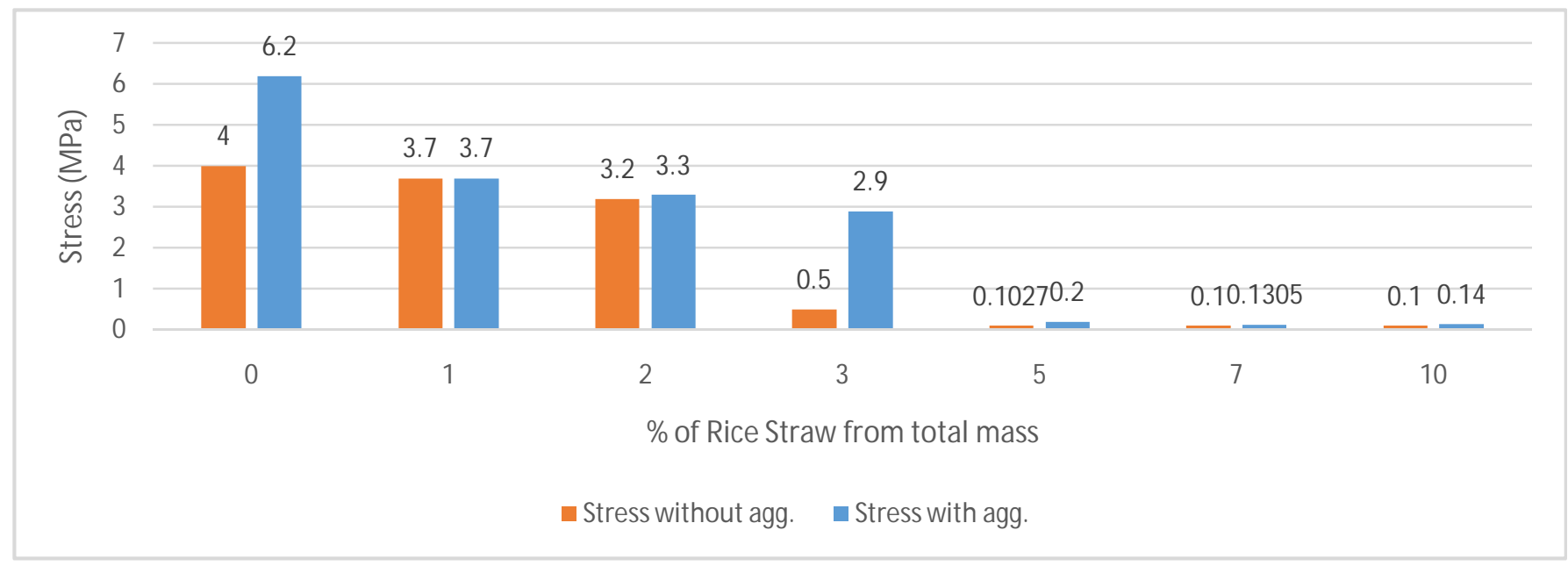

Figure 9 :Dependence of compression resistance on percent of rice straw for the standard brick consists of cement-sand (1:4) and Cement bricks consists of cement, sand and aggregate (1:2:2)

It is clear in figure that as the amount of rice straw added, the compression strength of mixture decreases gradually from 0 to $3 \%$ addition of rice straw as show in figure. More than $3 \%$ of rice straw added to cement brick mixture leads to drop in compression strength though the difference in the amount of cement between $3 \%$ mixture with aggregate comparing.

In addition, chemical analysis of rice straw bricks and cement bricks were investigated by Gihan, 2011. Results were the amount of calcium oxide and silicon oxide in cement bricks slightly higher than the rice straw bricks. Calcium oxide and silicon oxide are responsible of the Cementous activity when reacted with water. Furthermore, properties of both bricks were nearly the same. However, it may depend on the percentage of rice straw addition. Rice straw increase water absorption and consume high amount of water during preparation. Therefore, rice straw decrease efficiency of usage as a material for construction bricks. However, it is overcome permeability of water absorption is by facing mortar of cement lime stucco or may need more time for curing and gain more strength with time.

\subsection{Sound Insulation Test}

Source sound pressure level $=62 \mathrm{~dB}$

- Sound insulation test for cement bricks of ratio 1:2:2 Sound pressure level of cement bricks 1:2:2 ratio $=$ $55 \mathrm{~dB}$

Sound insulation of cement bricks $1: 2: 2$ ratio $=7 \mathrm{~dB}$

- Sound pressure level of $3 \%$ rice straw of cement mixture ratio $1: 2: 2$

Sound pressure level of 3\% rice straw of cement mixture ratio $1: 2: 2$ bricks $=45 \mathrm{~dB}$
Sound insulation of $3 \%$ rice straw of cement mixture ratio $1: 2: 2$ bricks $=17 \mathrm{~dB}$

It is clear from experimental result of sound insulation of cement bricks have 3\% of rice straw addition is better and higher than sound insulation of cement bricks performance for same ratio of concrete mixture 1:2:2. This is means that rice straw has good sound absorption.

\subsection{Thermal Insulation Test}

Heater plates are used to heat region that separate them $20 \mathrm{~cm}$. Temperature of the plates adjusted at about $250{ }^{\circ} \mathrm{C}$. The space temperature between two plates is $60^{\circ} \mathrm{C}$.

Thermal insulation in door of cement bricks of ratio $1: 2: 2$

Cement brick involve in mixture is cement, sand, and aggregate of ratio 1:2:2. Temperature inside room of cement brick is about $38{ }^{\circ} \mathrm{C}$ after 5 minutes of test.

$$
\Delta \mathrm{T}=60-38=22^{\circ} \mathrm{C}
$$

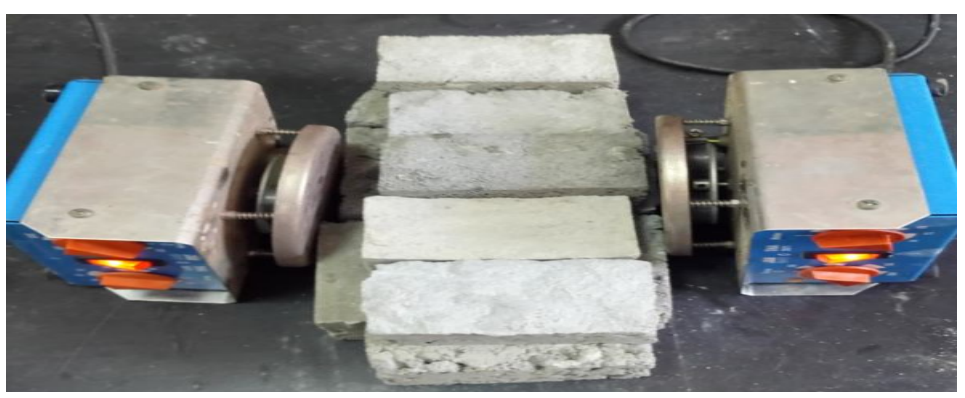

Figure 10 Thermal insulation test of cement bricks of ratio 1:2:2 by Ex-tech 5-in-1 Environmental meter

Thermal insulation in door of cement bricks of ratio $1: 2: 2$ with $3 \%$ of rice straw

Rice straw on cement bricks Influences the thermal insulation. Rice straw-cement bricks consists of 
Hend Ahmed et al., International Journal of Emerging Trends in Engineering Research, 8(10), October 2020, 7393 - 7403

cement, sand, and aggregates of ratio 1:2:2 with addition $3 \%$ rice straw. Temperature indoor is $30^{\circ} \mathrm{C}$ after 5 minutes of test.

$\Delta \mathrm{T}=\mathbf{6 0}-\mathbf{3 0}=\mathbf{3 0}{ }^{\circ} \mathrm{C}$

Comparison between cement bricks of ratio 1:2:2 with cement bricks with same ratio after adding $3 \%$ rice straw:

$$
\% \text { Reduction }=\frac{(38-30) * 100}{38}=21.05 \%
$$

Thermal insulation is one of the important properties for bricks of constructions. It is directly proportional with energy saving. Thermal conductivity of normal market cement brick is $1.25 \mathrm{Watt} / \mathrm{m} . \mathrm{K}$ (Akmal T. et al., 2011). According to Elhelece, 2010, studies show that major component in Egyptian rice straw is cellulose with $41.8 \%$ wt about half content of rice straw. Cellulose has thermal conductivity of range $0.031-0.042 \mathrm{Wm}^{-1} \mathrm{~K}^{-1}$ (Nguyen, 2014). However, thermal conductivity of market cement brick mixture is $0.5 \mathrm{Wm}^{-1} \mathrm{~K}^{-1}$. Content of cellulose with high content may have major effect of good performance of cement bricks with rice straw.

4.6 Impact of additives (as: glass powder \& nanosilicon) on compression resistance of cement brick with ratio of market $1: 4: 5$ and $3 \%$ rice straw.

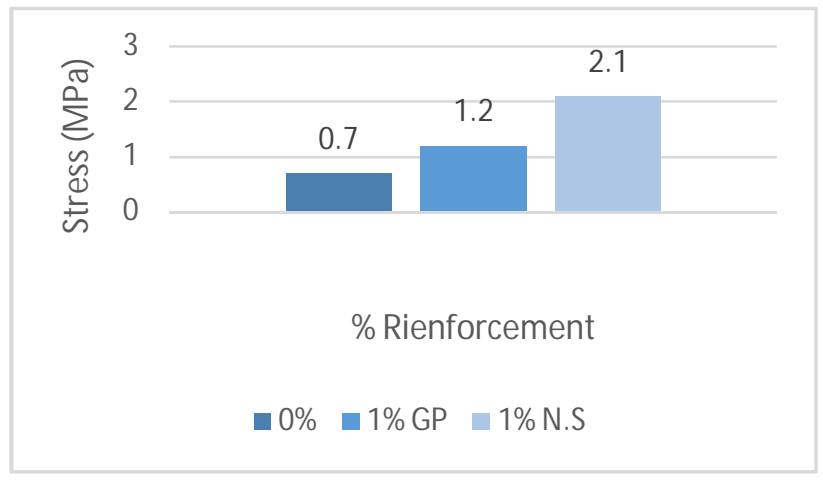

Figure 11Impact of additives (such as nano-silicon and glass powder) to Cement bricks mixture of ratio $(1: 4: 5)$ with $3 \%$ of rice straw.

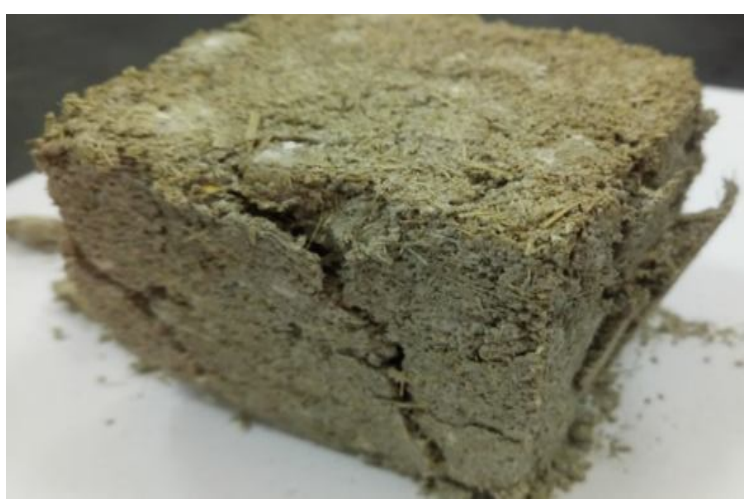

Figure 123\% Rice Straw-Cement bricks with 1\% of Nanosilicon from mass of sand after compression test
Rice straw is added with 3\% from total mass of mixture to commercial mixture of cement bricks which is ratio 1:4:5. It is clear that this sample does not achieve the minimum compression specification for non-load bearing bricks. Glass powder and nanosilicon have similar physical properties of sand. However, they have different surface area competing with each other and with sand. This difference may effect on compression strength of bricks. From left to the right on graph figure above, surface area of additive increase for same $1 \%$ percentage as a replacing portion of sand. As shown in figure above, the higher surface area, the higher brick resistance against load and this may be due to filling porosity that caused by addition of rice straw. However, Shayan A. et al. 2004, study the effect of adding waste glass powder on cement bricks. Waste glass powder is replaced portion of cement with $10 \%$ and $25 \%$ comparing with the control bricks.

The result of this research, both bricks with additives gives compression strength greater than 12 $\mathrm{MPa}$ but is less than the control sample after 4 days of curing. Although, compression strength of brick with $10 \%$ waste glass powder was slightly higher than control after curing 365 days.

$\%$ Price reduction of cement brick with 3\% rice straw comparing with cement brick of market ratio (1:4:5) $=\frac{(495-454) * 100}{495}=8.3 \%$

Table 1 Summary Table

\begin{tabular}{|c|c|c|c|c|}
\hline Bricks & $\begin{array}{l}\text { Compressio } \\
\text { n strength } \\
\text { (MPa) }\end{array}$ & $\begin{array}{c}\text { Thermal } \\
\text { insulatio } \\
\mathbf{n} \Delta \mathrm{T} \\
\left({ }^{\mathbf{C}} \mathrm{C}\right)\end{array}$ & $\begin{array}{c}\text { Sound } \\
\text { insulatio } \\
\mathbf{n} \\
\text { (dB) }\end{array}$ & $\begin{array}{c}\text { Price } \\
\text { (L.E./100 } \\
0 \text { bricks) } \\
\text { of } 6 * 6 * 6 \\
\text { cm } \\
\text { dimensio } \\
\text { n bricks }\end{array}$ \\
\hline $\begin{array}{c}\text { Cement } \\
\text { brick of } \\
\text { ratio } 1: 2: 2\end{array}$ & 6.2 & 22 & 7 & 576 \\
\hline $\begin{array}{c}\text { Commerci } \\
\text { al market } \\
\text { bricks } \\
\text { based on } \\
\text { Opaki } \\
\text { Company } \\
\text { of ratio } \\
1: 4: 5\end{array}$ & 3.8 & - & - & 495 \\
\hline $\begin{array}{c}\text { Cement } \\
\text { bricks of } \\
\text { ratio 1:2:2 } \\
\text { with } \\
\text { adding } 3 \% \\
\text { rice straw }\end{array}$ & 2.9 & 30 & 17 & 454 \\
\hline
\end{tabular}

\section{CONCLUSION}

The main aim of this research is to produce green brick of cement based on rice straw with good characteristics of better thermal insulation and 
Hend Ahmed et al., International Journal of Emerging Trends in Engineering Research, 8(10), October 2020, 7393 - 7403

acoustic resistance than normal cement bricks. First, best mixture of concrete brick is selected before adding rice straw. Then, rice straw is added with various percentage based on total mass of dry mixture to selected concert brick mixture. The choice of cement brick based on rice straw depends on maximizing percentage of rice straw added corresponding to achieve minimum compression strength of non-load bearing Egyptian specification. Final experimental work is determining temperature inside room of those bricks and sound to compare with cement bricks for same ratio of mixture.Results of research are first the presence of aggregates in cement bricks increases its compression strength comparing with cement-sand bricks for same ratio. Second, the selection of highest compression resistance against load of cement bricks are 1:2:2 and 1:4:5 of 6.2 and 3.1 MPa. Those mixture of cement are selected for adding percentage of rice straw. Rice straw slightly affect to compression strength of cement bricks may be because of low density and increasing porosity of brick contains rice straw. The sample that has maximum percentage of rice straw achieving minimum compression strength of cement brick with maximum ratio 1:2:2 amount of rice straw is $3 \%$ of rice straw. Whilethe maximum percentage of rice straw added to Cement-Sand brick is $2 \%$ of rice straw added. Cement brick based on $3 \%$ rice

\section{ACKNOWLEDGEMENT}

We express our deep gratitude to British University in Egypt (BUE). This work was partially performed using the facilities at the Nanotechnology Research Centre (NTRC) at the British University in Egypt (BUE). The authors also declares that there is no conflict of interest.

\section{REFERENCES}

1. Chen S.T., Synthesis of Pd/Fe3O4 Hybrid Nanocatalysts with Controllable Interface and Enhanced Catalytic Activities for CO Oxidation, Journal of Physical Chemistry C, Vol. 116, pp. 2969-12976, March 2012.

2. Radwan N.R.E., El-Shall M.S., Hassan H.M.A., Synthesis and characterization of nanoparticle $\mathrm{Co3O} 4, \mathrm{CuO}$ and $\mathrm{NiO}$ catalysts prepared by physical and chemical methods to minimize air pollution, Applied Catalysis A: General, Vol. 331, pp. 8-18, August 2007.

3. Wang H.L., Ni(OH)(2) Nanoplates Grown on Graphene as Advanced Electrochemical Pseudocapacitor Materials, Journal of the American Chemical Society, Vol. 132, 21, pp. 7472-7477, February 2010. straw improves thermal by $21.05 \%$ comparing with 1:2:2 of cement brick.

Sound pressure level inside room of cement bricks 1:2:2 ratio based $3 \%$ of rice straw reduces from $62 \mathrm{~dB}$ to $45 \mathrm{bB}$. Comparing with cement brick of rice straw base, cement bricks reduce sound pressure level to $55 \mathrm{~dB}$. Cement brick of 1:2:2 based on $3 \%$ of rice straw mixture cost is $23.21 \%$ less than cement brick with same ratio and $8.3 \%$ less than cement brick of market ratio. This improvement of the characteristics of brick-based rice straw may be due to high content of cellulose in the composition of dry rice straw.Furthermore, green brick optimizes and reduces resources that used as aggregates and most expensive material is cement. However, Sample cement brick of 1:4:5 with 3\% of rice straw gives compression result less than minimum Egyptian specification. Glass powder and nano-silicon are used as a filler replace portion of sand contribute to increase strength of bricks against compression. Both are used for improving the compression stress results $1: 4: 5$ of $3 \%$ of rice straw. This mixture of $3 \%$ rice straw base with $1 \%$ nano-silicon addition percentage of sand portion gives highest compression of $2.1 \mathrm{MPa}$ comparing with $1 \%$ addition of glass powder and with $3 \%$ rice straw only and this may be because nano-silicon has the highest surface area and reduce porosity that caused by rice straw.

4. Wang W.W., Zhu Y.J., Ruan M.L., Microwave-assisted synthesis and magnetic property of magnetite and hematite nanoparticles, Journal of Nanoparticle Research, Vol. 9, 3, pp. 419-426, April 2007.

5. Elazab H., Microwave-assisted synthesis of Pd nanoparticles supported on $\mathrm{FeO}, \mathrm{CoO}$, and $\mathrm{Ni}(\mathrm{OH})$ nanoplates and catalysis application for CO oxidation, Journal of Nanoparticle Research, Vol. 16, 7, pp. 1-11, November 2014.

6. Mankarious R.A., et al., Bulletproof vests/shields prepared from composite material based on strong polyamide fibers and epoxy resin, Journal of Engineering and Applied Sciences, Vol. 12, 10, pp. 2697-2701, May 2017.

7. Mohsen W., Sadek M.A., Elazab H.A., Green synthesis of copper oxide nanoparticles in aqueous medium as a potential efficient catalyst for catalysis applications, International Journal of Applied Engineering Research, Vol. 12, 24, pp. 14927-14930, July 2017.

8. Mostafa A.R., Omar H.A.-S., Hany A.E., Preparation of Hydrogel Based on Acryl Amide and Investigation of Different Factors Affecting Rate and Amount of Absorbed 
Water, Agricultural Sciences, Vol. 8, pp. 2-11, June 2017.

9. Radwan M.A., et al., Mechanical characteristics for different composite materials based on commercial epoxy resins and different fillers, Journal of Engineering and Applied Sciences, Vol. 12, 5, pp. 1179-1185, May 2017.

10. Andrade A.L., Catalytic Effect of Magnetic Nanoparticles Over the $H(2) O(2)$ Decomposition Reaction, Journal of Nanoscience and Nanotechnology, Vol. 9, 6, pp. 3695-3699, June 2009.

11. Kustov A.L., CO methanation over supported bimetallic Ni-Fe catalysts: From computational studies towards catalyst optimization, Applied Catalysis a-General, Vol. 320, pp. 98-104, November 2007.

12. Lohitharn N., Goodwin J.G., Impact of Cr, Mn and $\mathrm{Zr}$ addition on $\mathrm{Fe}$ Fischer-Tropsch synthesis catalysis: Investigation at the active site level using SSITKA, Journal of Catalysis, Vol. 257, 1, pp. 142-151, August 2008.

13. Moreau F., Bond G.C., CO oxidation activity of gold catalysts supported on various oxides and their improvement by inclusion of an iron component, Catalysis Today, Vol. 114, 4, pp. 362-368, October 2006.

14. Sarkari M., Fischer-Tropsch synthesis: Development of kinetic expression for a solgel Fe-Ni/Al2O3 catalyst, Fuel Processing Technology, Vol. 97, pp. 130-139, April 2012.

15. Elazab H., The Effect of Graphene on Catalytic Performance of Palladium Nanoparticles Decorated with $\mathrm{FeO}, \mathrm{CoO}$, and Ni (OH): Potential Efficient Catalysts Used for Suzuki Cross-Coupling, Catalysis Letters, Vol. 147, 6, pp. 1510-1522, July 2017.

16. Elazab H.A., The continuous synthesis of $\mathbf{P d}$ supported on $\mathrm{Fe} 3 \mathrm{O} 4$ nanoparticles: A highly effective and magnetic catalyst for $\mathrm{CO}$ oxidation, Green Processing and Synthesis, Vol. 6, 4, pp. 413-424, May 2017.

17. Elazab H.A., Sadek M.A., El-Idreesy T.T., Microwave-assisted synthesis of palladium nanoparticles supported on copper oxide in aqueous medium as an efficient catalyst for Suzuki cross-coupling reaction, Adsorption Science \& Technology, Vol. 36, pp. 1352-1365, May2018.

18. Elazab H.A., Highly efficient and magnetically recyclable graphene-supported $\mathrm{Pd} / \mathrm{Fe} 304$ nanoparticle catalysts for Suzuki and Heck cross-coupling reactions, Applied Catalysis A: General, Vol. 491, pp. 58-69, February 2015.
19. Hirvi J.T., et al., CO oxidation on PdO surfaces, Journal of Chemical Physics, Vol. 133, pp. 8-14, August 2010.

20. Iglesias-Juez A., Nanoparticulate Pd Supported Catalysts: Size-Dependent Formation of $\operatorname{Pd}(\mathrm{I}) / \mathrm{Pd}(0)$ and Their Role in CO Elimination, Journal of the American Chemical Society, Vol. 133, 12, pp. 4484-4489, March 2011.

21. Ivanova A.S., Metal-support interactions in $\mathrm{Pt} / \mathrm{Al} 2 \mathrm{O3}$ and $\mathrm{Pd} / \mathrm{Al} 2 \mathrm{O3}$ catalysts for $\mathrm{CO}$ oxidation, Applied Catalysis B-Environmental, Vol. 97, 1-2, pp. 57-71, April 2010.

22. Kim H.Y., Henkelman G., CO Oxidation at the Interface between Doped $\mathrm{CeO} 2$ and Supported Au Nanoclusters, Journal of Physical Chemistry Letters, Vol. 3, 16, pp. 21942199, January 2012.

23. Chattopadhyay K., Dey R., Ranu B.C., Shapedependent catalytic activity of copper oxidesupported Pd(0) nanoparticles for Suzuki and cyanation reactions, Tetrahedron Letters: International Organ for the Rapid Publication of Preliminary Communications in Organic Chemistry, Vol. 50, 26. pp. 3164-3167, December 2009.

24. Hoseini S.J., Modification of palladium-copper thin film by reduced graphene oxide or platinum as catalyst for Suzuki-Miyaura reactions, Applied Organometallic Chemistry, Vol. 31, pp. 5-12, March 2017.

25. Hosseini-Sarvari M., Razmi Z., Palladium Supported on Zinc Oxide Nanoparticles as Efficient Heterogeneous Catalyst for Suzuki Miyaura and Hiyama Reactions under Normal Laboratory Conditions, Helvetica Chimica Acta, Vol. 98, 6, pp. 805-818, April 2015.

26. Nasrollahzadeh M., Ehsani A., Jaleh B., Preparation of carbon supported $\mathrm{CuPd}$ nanoparticles as novel heterogeneous catalysts for the reduction of nitroarenes and the phosphine-free Suzuki Miyaura coupling reaction, New Journal of Chemistry, Vol. 39, 2, pp. 1148-1153, February 2015.

27. Nasrollahzadeh M., Palladium nanoparticles supported on copper oxide as an efficient and recyclable catalyst for carbon(sp2) carbon(sp2) cross-coupling reaction, Materials Research Bulletin, Vol. 68, pp. 150-154, April 2013.

28. Mandali P.K., Chand D.K., Palladium nanoparticles catalyzed Suzuki cross-coupling reactions in ambient conditions, Catalysis Communications, Vol. 31, pp.16-20, November 2016. 
29. Wang Y., CuO Nanorods-Decorated Reduced Graphene Oxide Nanocatalysts for Catalytic Oxidation of CO, Catalysts, Vol. 6, 12, pp. 214220, September 2016.

30. Igarashi H., Uchida H., Watanabe M., Mordenite-supported noble metal catalysts for selective oxidation of carbon monoxide in a reformed gas, Chemistry Letters, Vol. 11, pp. 1262-1263, October 2000.

31. Liu W.H., Fleming S., Lairson B.M., Reduced intergranular magnetic coupling in $\mathrm{Pd} / \mathrm{Co}$ multilayers, Journal of Applied Physics, Vol. 79, 7, pp. 3651-3655, May 1996.

32. Luo J.Y., Mesoporous $\operatorname{Co}(3) \mathrm{O}(4)-\mathrm{CeO}(2)$ and $\mathrm{Pd} / \mathrm{Co}(3) \mathrm{O}(4)-\mathrm{CeO}(2)$ catalysts: Synthesis, characterization and mechanistic study of their catalytic properties for low-temperature CO oxidation, Journal of Catalysis, Vol. 254, 2, pp. 310-324, June 2008.

33. Pavlova S.N., The influence of support on the low-temperature activity of $\mathrm{Pd}$ in the reaction of $\mathrm{CO}$ oxidationonKinetics and mechanism of the reaction, Journal of Catalysis, Vol. 161, 2, pp. 517-523, May 1996.

34. Diyarbakir S.M., Can H., Metin Ã.n., Reduced Graphene Oxide-Supported CuPd Alloy Nanoparticles as Efficient Catalysts for the Sonogashira Cross-Coupling Reactions, Acs Applied Materials \& Interfaces, Vol. 7, 5, pp. 3199-3206, March 2015.

35. Feng Y.-S., et al., ChemInform Abstract: PdCu Nanoparticles Supported on Graphene: An Efficient and Recyclable Catalyst for Reduction of Nitroarenes, ChemInform, Vol. 46, pp. 4-12, August 2015.

36. Feng Y.-S., et al., $\mathbf{P d C u}$ nanoparticles supported on graphene: an efficient and recyclable catalyst for reduction of nitroarenes, Tetrahedron, Vol. 70, 36, pp. 61006105, May 2014.

37. Liu Y., et al., Ultrasensitive electrochemical immunosensor for SCCA detection based on ternary $\mathbf{P t} / \mathbf{P d C u}$ nanocube anchored on three-dimensional graphene framework for signal amplification, Biosensors \& Bioelectronics, Vol. 79, pp. 71-78, July 2016.

38. Shafaei Douk A., Saravani H., Noroozifar M., Novel fabrication of $\mathrm{PdCu}$ nanostructures decorated on graphene as excellent electrocatalyst toward ethanol oxidation, International Journal of Hydrogen Energy, Vol. 42, 22, pp. 15149-15159, August 2017.

39. Hany A. Elazab, Investigation of Microwaveassisted Synthesis of Palladium Nanoparticles Supported on $\mathrm{Fe}_{3} \mathrm{O}_{4}$ as an Efficient Recyclable Magnetic Catalysts for Suzuki Cross Coupling, The Canadian Journal of Chemical
Engineering, Vol. 96, 12, pp. 250-261, January 2019.

40. Hany A. Elazab,Laser Vaporization and Controlled Condensation (LVCC) of Graphene supported $\mathrm{Pd} / \mathrm{Fe}_{3} \mathrm{O}_{4}$ Nanoparticles as an Efficient Magnetic Catalysts for Suzuki Cross - Coupling, Biointerface Research in Applied Chemistry, Vol. 8, 3, pp. 3314 - 3318, August 2018.

41. Hany A. Elazab, The catalytic Activity of Copper Oxide Nanoparticles towards Carbon Monoxide Oxidation Catalysis: Microwave Assisted Synthesis Approach, Biointerface Research in Applied Chemistry, Vol. 8, 3, pp. 3278 - 3281, June 2018.

42. M. A. Radwan, Omar Al-Sweasy, M. A. Sadek, Hany A. Elazab, Investigating the Agricultural Applications of Acryl Amide based Hydrogel, International Journal of Engineering and Technology(UAE), Vol. 7, 4.29, pp. 168-171, April 2018.

43. Fatma Zakaria, M. A. Radwan, M. A. Sadek, Hany A. Elazab, Insulating material based on shredded used tires and inexpensive polymers for different roofs, International Journal of Engineering and Technology(UAE), Vol. 7, 4, pp. 1983-1988, June 2018.

44. Reem Nasser, M. A. Radwan, M. A. Sadek, Hany A. Elazab, Preparation of insulating material based on rice straw and inexpensive polymers for different roofs, International Journal of Engineering and Technology(UAE), Vol. 7, 4, pp. 1989-1994, June 2018.

45. Mostafa Ghobashy, Mamdouh Gadallah, Tamer T. El-Idreesy, M. A. Sadek, Hany A. Elazab, Kinetic Study of Hydrolysis of Ethyl Acetate using Caustic Soda, International Journal of Engineering and Technology(UAE), Vol. 7, 4, pp. 1995-1999, June 2018.

46. Nourhan Sherif Samir, Mostafa A. Radwan, M. A. Sadek, Hany A. Elazab, Preparation and Characterization of Bullet-Proof Vests Based on Polyamide Fibers, International Journal of Engineering and Technology(UAE), Vol. 7, 3, pp. 1290-1294, May 2018.

47. Basant Ashraf, Mostafa A. Radwan, M. A. Sadek, Hany A. Elazab, Preparation and Characterization of Decorative and Heat Insulating Floor Tiles for Buildings Roofs, International Journal of Engineering and Technology (UAE), Vol. 7, 3, pp. 1295-1298, May 2018.

48. Mandali P.K., Chand D.K., Palladium nanoparticles catalyzed Suzuki cross-coupling reactions in ambient conditions, Catalysis Communications, Vol. 31, 5, pp. 16-20, October 2016. 
49. Wang Y., CuO Nanorods-Decorated Reduced Graphene Oxide Nanocatalysts for Catalytic Oxidation of CO, Catalysts, Vol. 6, 12, pp. 214223, April 2016.

50. Pavlova S.N., The influence of support on the low-temperature activity of $\mathrm{Pd}$ in the reaction of $\mathrm{CO}$ oxidation on Kinetics and mechanism of the reaction, Journal of Catalysis, Vol. 161, 2, pp. 517-523, July 1996.

51. Diyarbakir S.M., Can H., Metin Ã.n., Reduced Graphene Oxide-Supported CuPd Alloy Nanoparticles as Efficient Catalysts for the Sonogashira Cross-Coupling Reactions, Acs Applied Materials \& Interfaces, Vol. 7, 5, pp. 3199-3206, June 2015.

52. M. A. Radwan, Mohamed Adel Rashad, M. A. Sadek, Hany A. Elazab, Synthesis, Characterization and Selected Application of Chitosan Coated Magnetic Iron Oxide Nanoparticles, Journal of Chemical Technology and Metallurgy, Vol. 54, 2, pp. 303-310, June 2019.

53. Hosam H. Abdelhady, Hany A. Elazab, Emad M. Ewais, Mohamed Saber, Mohamed S. El-Deab, Efficient Catalytic Production of Biodiesel Using Nano-Sized Sugarbeet Agro-Industrial waste, Fuel, Vol. 261, pp. 116481, February 2020.

54. Hany A. Elazab, M. A. Sadek, Tamer T. ElIdreesy, Facile Synthesis of Reduced Graphene Oxide-Supported $\mathrm{Pd} / \mathrm{CuO}$ Nanoparticles as an Efficient Catalyst for Cross-Coupling Reactions, Journal of Chemical Technology and Metallurgy, Vol. 54, 5, pp. 934946, August 2019.

55. Hany A. Elazab, Tamer T. El-Idreesy, Polyvinylpyrrolidone - Reduced Graphene Oxide - Pd Nanoparticles as an Efficient Nanocomposite for Catalysis Applications in Cross-Coupling Reactions, Bulletin of Chemical Reaction Engineering and Catalysis, Vol. 14, 3, pp. 490-501, December 2019.

56. Hany A. Elazab, Ali R. Siamaki, B. Frank Gupton, M. Samy El-Shall, Pd-Fe $\mathbf{O}_{3} \mathbf{O}_{4} /$ RGO: a Highly Active and Magnetically Recyclable Catalyst for Suzuki Cross Coupling Reaction using a Microfluidic Flow Reactor, Bulletin of Chemical Reaction Engineering and Catalysis, Vol. 14, 3, pp. 478-489, December 2019.

57. Hany A. Elazab, M. A. Radwan, Tamer T. ElIdreesy, Facile microwave-assisted synthetic approach to palladium nanoparticles supported on copper oxide as an efficient catalyst for Heck cross-coupling reactions, International Journal of Nanoscience, Vol. 18, 5, pp. 1850032, June 2019.
58. Hany A. Elazab, S. A. Hassan, M. A. Radwan, M. A. Sadek, Microwave-assisted Synthesis of Graphene supported Hexagonal Magnetite for Applications in Catalysis, International Journal of Innovative Technology and Exploring Engineering (IJITEE), Vol. 8, 12, 5511-5513, 2019.

59. Hany A. Elazab, M. A. Radwan, M. A. Sadek, Hydrothermal Synthesis of Palladium nanoparticles supported on $\mathrm{Fe}_{3} \mathrm{O}_{4}$ Nanoparticles: an Efficient Magnetic Catalysts for CO Oxidation, International Journal of Innovative Technology and Exploring Engineering (IJITEE), Vol. 8, 12, pp. 2792-2794, May 2019.

60. Tarek M. Aboul-Fotouh, Sherif K. Ibrahim, M. A. Sadek, Hany A. Elazab, High Octane Number Gasoline-Ether Blend, International Journal of Innovative Technology and Exploring Engineering (IJITEE), Vol. 8, 9, pp. 732-739, March 2019.

61. Tarek M. Aboul-Fotouh, Islam Alaa, M. A. Sadek, Hany A. Elazab, Physico-Chemical Characteristics of Ethanol-Diesel Blend Fuel, International Journal of Innovative Technology and Exploring Engineering (IJITEE), Vol. 8, 9, pp. 740-747, February 2019.

62. Hany A. Elazab, M. M. Seleet, Said M. A. Hassanein, M. A. Radwan, M. A. Sadek, Synthesis and Characterization of Dinitro Pentamethylene Tetramine (DPT), Journal of Advanced Research in Dynamical and Control System, Vol. 11, 5S, pp. 310-318, August 2019.

63. Hany A. Elazab, M. M. Seleet, Said M. A. Hassanein, M. A. Radwan, M. A. Sadek, Followup and Kinetic Model Selection of Dinitro Pentamethylene Tetramine (DPT), International Journal of Innovative Technology and Exploring Engineering (IJITEE), Vol. 8, 8, pp. 2862-2866, October 2019.

64. Hany A. Elazab, Mamdouh Gadall, M. A. Sadek, Tamer T. El-Idreesy, Hydrothermal Synthesis of Graphene supported $\mathrm{Pd} / \mathrm{Fe}_{3} \mathrm{O}_{4}$ Nanoparticles as an Efficient Magnetic Catalysts for Suzuki Cross - Coupling, Biointerface Research in Applied Chemistry, Vol. 9, 2, pp. 3906-3911, March 2019.

65. Hany A. Elazab, M. M. Seleet, Said M. A. Hassanein, M. A. Radwan, M. A. Sadek, 3,7Dinitro-1,3,5,7-Tetraazabicyclo[3,3,1]Nonane (DPT): An Important Intermediate in the Synthesis Route of one of the Most Powerful Energetic Materials (RDX/HMX), International Journal of Innovative Technology and Exploring Engineering (IJITEE), Vol. 8, 452, pp. 88-95, April 2019. 
66. Hany A. Elazab, Tamer T. El-Idreesy, Optimization of the Catalytic Performance of $\mathrm{Pd} / \mathrm{Fe}_{3} \mathrm{O}_{4}$ Nanoparticles Prepared via Microwave-assisted Synthesis for Pharmaceutical and Catalysis Applications, Biointerface Research in Applied Chemistry, Vol. 9, 1, pp. 3794-3799, July 2019.

67. Hany A. Elazab, Yousab G. Remiz, Mostafa A. Radwan, M. A. Sadek, Synthesis and Characterization of Chitosan Based Catalyst for Catalysis Applications, International Journal of Advanced Trends in Computer Science and Engineering (IJATCSE), Volume 9, Issue 1, PP. 521-527, February 2020.

68. Hassaan M. Shehata, Dalia A. Ali, Islam M. AlAkraa, Hoda A. Elsawy, Hany A. Elazab, Development of novel adsorbent for industrial wastewater treatment, International Journal of Advanced Trends in Computer Science and Engineering (IJATCSE), Volume 9, Issue 1, PP. 704712, February 2020.

69. M. H. El Dewaik, Mamdouh Gadalla, M. A. Sadek, Hany A. Elazab, Mathematica as an Efficient Tool to Optimize the Kinetic Study of Ethyl Acetate Hydrolysis, International Journal of Advanced Trends in Computer Science and Engineering (IJATCSE), Volume 9, Issue 1, PP. 691697, February 2020. 